\title{
Vitamin A status and the metabolism of cholesterol in the rat
}

\author{
By M. R. LAKSHMANAN, W. E. J. PHILLIPS AND R. L. BRIEN \\ Research Laboratories, Food and Drug Directorate, \\ Department of National Health and Welfare, Ottawa, Canada
}

(Received 26 March I968-Accepted 23 August I968)

\footnotetext{
x. The interrelationship between cholesterol and vitamin A metabolism has been studied in rats.

2. The effect of cholesterol feeding in increasing the liver storage of cholesterol was enhanced during vitamin A deficiency.

3. This effect was due to an increased rate of absorption of cholesterol and not due to a decreased turnover rate.

4. Feeding of high levels of vitamin A markedly depressed the cholesterol absorption; however, its turnover was unaffected.
}

The importance of blood lipids in general and cholesterol in particular in the pathogenesis of atherosclerosis has led to a search for dietary regimens to control hypercholesterolaemia. Dietary fish oils are effective in lowering serum cholesterol (Bronte-Stewart, Antonis, Eales \& Brock, 1956; Anderson, Keys \& Grande, I957; Ahrens, Insull, Hirsch, Stoffel, Peterson, Farquhar, Miller \& Thompson, 1959; DeGroot \& Reed, 1959). In studies using chickens Wood (1960) demonstrated that vitamin A was the active hypocholesterolaemic factor in fish oils. Later, it was shown that vitamin A feeding prevented the rise in serum and liver cholesterol levels induced by dietary cholesterol in rats (Bring, Ricard \& Zaehringer, 1965) and chickens (Wood \& Topliff, 1961; Beeler, Rogler \& Quackenbush, 1962; March \& Biely, 1963). Sampson \& Potter (1947) in a brief communication reported that vitamin A-deficient rats stored more cholesterol than controls when maintained on a diet containing cholesterol. On the other hand, Green, Horner, Lowe \& Morton (1957) concluded that cholesterol feeding decreased liver vitamin A storage in male rats. All these studies suggest an inverse relationship between cholesterol and vitamin A but the exact mechanism by which this is manifested is not fully understood. The most likely processes through which vitamin A or cholesterol may control the metabolism of each other are ( $a$ ) absorption across the intestine, $(b)$ transport and storage in the liver, and $(c)$ turnover rate.

The present investigations were undertaken in an attempt to elucidate the complex interrelationships between cholesterol and vitamin A metabolism.

\section{EXPERIMENTAL}

Animals. Albino rats of the Wistar strain were weaned at $2 \mathrm{I}$ days of age and fed the appropriate experimental diets $a d$ lib.

Analysis of tissues. Tissues from each group were bulked and saponified in Expts I and 2; in Expts 3 and 4 individual tissues were saponified (in the presence of ethanolic 
pyrogallol). The non-saponifiable fraction was chromatographed on neutral alumina partially deactivated to Brockman grade 3 , as described by Mervyn \& Morton (1959). The vitamin A and sterol fraction was isolated as described previously (Phillips, I 967). Absorption spectra were determined over the range of $220 \mathrm{~nm}$ to $360 \mathrm{~nm}$ with a recording spectrophotometer.

Radioactive tracer and assay. $\left[4^{-14} \mathrm{C}\right]$ Cholesterol (specific activity $30 \cdot 2 \mathrm{mc} / \mathrm{mM}$ ) with a radiochemical purity greater than $99 \%$ was obtained from the Radiochemical Centre, Amersham. The material to be assayed for radioactivity was dissolved in toluene containing $0.5 \%(\mathrm{w} / \mathrm{v})$ 2,5-diphenyloxazole and $0.03 \%(\mathrm{w} / \mathrm{v})$ $)$, 4 -bis[2-(5-phenyloxazolyl)]benzene and counted in a liquid scintillation spectrometer (Nuclear Chicago Inc.) using the channel ratio method to account for quenching.

Expt I. Twenty male weanling rats were allocated randomly to one of four diets. The basal diet for all groups was free from cholesterol and fat and had the following composition: vitamin-free casein $25 \%$, sucrose $55 \%$, Alphacel $16 \%$, USP I4 salt $\operatorname{mix} 4 \%$, and a vitamin fortification mixture (Nutritional Biochemical Corp., Cleveland, Ohio) with vitamin A omitted. The vitamins added per $\mathrm{kg}$ diet were: thiamine hydrochloride $22 \mathrm{mg}$, riboflavine $22 \mathrm{mg}$, calcium pantothenate $7 \mathrm{I} \mathrm{mg}$, nicotinic acid $88 \mathrm{mg}$, pyridoxol hydrochloride $22 \mathrm{mg}$, menaphthone $40 \mathrm{mg}, \alpha$-tocopherol I $10 \mathrm{mg}$, folic acid $2.2 \mathrm{mg}$, biotin $0.4 \mathrm{mg}, p$-aminobenzoic acid I Io $\mathrm{mg}$, inositol I $10 \mathrm{mg}$, calciferol $0.06 \mathrm{mg}$, choline chloride $\mathrm{I} .68 \mathrm{~g}$. Two groups were fed on this diet supplemented with vitamin A (1000o i.u./ $/ \mathrm{kg}$ in the form of stabilized vitamin A powder of potency 20000 i.u./g; Nutritional Biochemical Corp., Cleveland, Ohio) and the other two groups received the basal ration with no vitamin A supplement. Cholesterol in powder form at a level of $2 \%$ was incorporated into half of each of the above diets.

Treatments were replicated four times, a total of eighty rats being used. The experimental design is shown in Table $\mathrm{I}$. The results were subjected to analysis of variance and individual degrees of freedom were isolated for vitamin $A$, sterol, and the interaction.

Expt 2. Expt 2 was designed to study the effects on the liver non-saponifiables of dietary cholesterol when dissolved in oil. A vitamin A-free diet (Phillips, 196I) containing $5 \%$ cottonseed oil was used as the basal diet. Thirty-two animals, sixteen of each sex, were divided into eight groups of four rats. The experimental design is shown in Table 2. Each group of rats received either cholesterol (final concentration $2 \%$ in the whole diet) or vitamin A (10000 i.u. $/ \mathrm{kg}$ ) or both.

Expt 3. Sixty-four male weanling rats were divided into two groups of thirty-two rats each and while one was maintained on the vitamin A-free basal diet the other was fed on this diet supplemented with vitamin A (I0000 i.u./kg). Rats fed on the vitamin A-free diet ceased gaining weight after 4-5 weeks. At this stage of vitamin Adeficiency rats from both groups received, by stomach tube, a dose of I $\mathrm{mg}$ cholesterol having a radioactivity of $2 \mu \mathrm{c}$ in $0.5 \mathrm{ml}$ cottonseed oil. Eight animals from each group were killed 4, 6, 12 and $24 \mathrm{~h}$ after the tracer dose, as shown in Fig. $\mathrm{r}$. The small intestine, from the pyloric sphincter to the ileocaecal junction, and the liver were excised. Unabsorbed material in the intestinal lumen was removed by flushing with 
$50 \mathrm{ml}$ of ice-cold physiological saline. The liver and intestine were analysed for radioactivity in the non-saponifiable fraction. The radioactivity in the non-saponifiable fraction as such was taken as a measure of the radioactivity in the sterol fraction since in the initial experiments it was found that after chromatography on deactivated alumina and precipitation with digitonin more than $95 \%$ of the radioactivity from the non-saponifiable fraction of these tissues remained in the digitonide precipitate.

Expt 4. Seventy-two male weanling rats were divided into three groups of twentyfour and maintained on diet I (vitamin A-free basal diet), diet 2 (diet I + 400 i.u. vitamin $\mathrm{A} / \mathrm{kg}$ diet) or diet 3 (diet $\mathrm{I}+40000$ i.u. vitamin $\mathrm{A} / \mathrm{kg} \operatorname{diet}$ ). When the rats on diet I reached the weight plateau stage of vitamin A deficiency, each rat from all the groups was dosed by stomach tube with I $\mathrm{mg}$ cholesterol in $0.5 \mathrm{ml}$ cottonseed oil (radioactivity $\mathrm{I} \mu \mathrm{c}$ ). The rats to be killed $96 \mathrm{~h}$ after the tracer dose each received $2 \mu \mathrm{c}$ cholesterol. Six animais from each group were killed $24,48,72$ and $96 \mathrm{~h}$ after dosing and the livers and intestines were analysed for radioactivity in the non-saponifiable fraction as described in Expt 3.

\section{RESULTS}

Expt I was terminated after giving the experimental diet for $3^{6}$ days. Animals not receiving a dietary supplement of vitamin $A$ were at the plateau stage of the deficiency syndrome. Although vitamin A influenced growth $(P=0.01)$, the feeding of $2 \%$ cholesterol did not modify growth or liver weight either in the presence or absence of vitamin A (Table I). Feeding $2 \%$ cholesterol increased $(P=0.01)$ the percentage of

\section{Table 1. Expt 1. Effect of dietary cholesterol and vitamin $A$ in a fat-free diet on some liver non-saponifiable constituents of rats}

(Mean values with their standard errors for four replicate determinations)

\begin{tabular}{|c|c|c|c|c|c|}
\hline \multicolumn{2}{|c|}{ Treatment } & \multirow{2}{*}{$\begin{array}{l}\text { Final body-wt } \\
\text { (g) }\end{array}$} & \multirow{2}{*}{$\begin{array}{c}\text { Liver wt } \\
\text { (g) }\end{array}$} & \multirow{2}{*}{$\begin{array}{c}\text { Non-saponifiables } \\
(\%)\end{array}$} & \multirow{2}{*}{$\begin{array}{l}\text { Sterol in liver } \\
(\mathrm{mg} / \mathrm{g})\end{array}$} \\
\hline Vitamin & A Cholesterol & & & & \\
\hline+ & - & $24 I \pm I$ & II.I7士0.17 & $0.383 \pm 0.008$ & $2.48 \pm 0.07$ \\
\hline+ & + & $236 \pm 3$ & $10.95 \pm 0.19$ & $0.553 \pm 0.024$ & $3.78 \pm 0.39$ \\
\hline- & - & $189 \pm 6$ & $7.88 \pm 0.27$ & $0.408 \pm 0.013$ & $2.65 \pm 0.07$ \\
\hline- & + & $184 \pm 4$ & $7 \cdot 85 \pm 0.18$ & $1 \cdot 182 \pm 0.204$ & $8 \cdot 90 \pm 1 \cdot 30$ \\
\hline
\end{tabular}

liver non-saponifiable constituents, the increase being greater in those animals not receiving dietary vitamin $A$ than in those receiving vitamin $A(P=0.05)$. A parallel effect was observed in the concentration of liver crude sterol. The effects of vitamin $A$, cholesterol feeding and the interaction between vitamin $\mathrm{A}$ and cholesterol feeding were all highly significant $(P=0.01)$. The accumulation of liver sterol in animals receiving $2 \%$ dietary cholesterol was less in the presence of vitamin $A$ than in its absence.

In Expt 2 it was necessary to kill the male animals after 45 days feeding and the females after 55 days, owing to the sex difference in reaching the avitaminotic state. The effects of dietary treatments on hepatic sterols are shown in Table 2. The relative concentrations of liver sterols resulting from the feeding of cholesterol dissolved in 
the dietary oil was similar to that observed in Expt $\mathrm{I}$. The degree of absorption and consequent levels of liver sterol were much greater, however. The extremely high accumulation of liver sterols in the male vitamin A-deficient group receiving cholesterol (group 4) would appear to be a direct reflection of the degree of avitaminosis. This group exhibited the most severe weight loss of all groups on the deficient diet.

Table 2. Expt 2. Effect of dietary cholesterol and vitamin $A$ on some liver non-saponifiable constituents of rats

\begin{tabular}{|c|c|c|c|c|c|c|c|c|}
\hline \multirow[b]{2}{*}{ Group } & \multicolumn{2}{|c|}{ Treatment } & \multirow[b]{2}{*}{ Sex } & \multirow{2}{*}{$\begin{array}{l}\text { Mean } \\
\text { maximum } \\
\text { body-wt } \\
\text { (g) }\end{array}$} & \multirow{2}{*}{$\begin{array}{c}\text { Mean } \\
\text { final } \\
\text { body-wt } \\
\text { (g) }\end{array}$} & \multirow[b]{2}{*}{$\begin{array}{c}\text { Mean } \\
\text { liver wt } \\
\text { (g) }\end{array}$} & \multirow[b]{2}{*}{$\begin{array}{c}\text { Non- } \\
\text { saponifiables } \\
(\%)\end{array}$} & \multirow{2}{*}{$\begin{array}{l}\text { Sterol } \\
\text { in } \\
\text { liver } \\
(\mathrm{mg} / \mathrm{g})\end{array}$} \\
\hline & Vitamin A & $\begin{array}{l}\text { Choles- } \\
\text { terol }\end{array}$ & & & & & & \\
\hline $\mathbf{I}$ & $t$ & - & ô & 180 & 180 & 10.28 & 0.342 & $2 \cdot 23$ \\
\hline 2 & + & + & 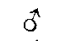 & $21 I$ & 2 II & 14.34 & $I \cdot 356$ & I I 49 \\
\hline 3 & - & - & $0^{x}$ & 125 & I I 3 & 5.10 & 0.458 & $2 \cdot 18$ \\
\hline 4 & - & + & $\sigma^{\star}$ & I 37 & II 4 & $7 \cdot 11$ & 5.530 & $40 \cdot 39$ \\
\hline 5 & + & - & 우 & I 77 & I77 & $7 \cdot 76$ & 0.372 & $2 \cdot 28$ \\
\hline 6 & + & + & 우 & 174 & 174 & $8 \cdot 35$ & 0.897 & $7 \cdot 58$ \\
\hline 7 & - & - & 우 & 126 & 109 & 3.60 & 0.523 & $2 \cdot 74$ \\
\hline 8 & - & + & 우 & 143 & I3I & 5.96 & $I \cdot 842$ & I $1 \cdot 65$ \\
\hline
\end{tabular}
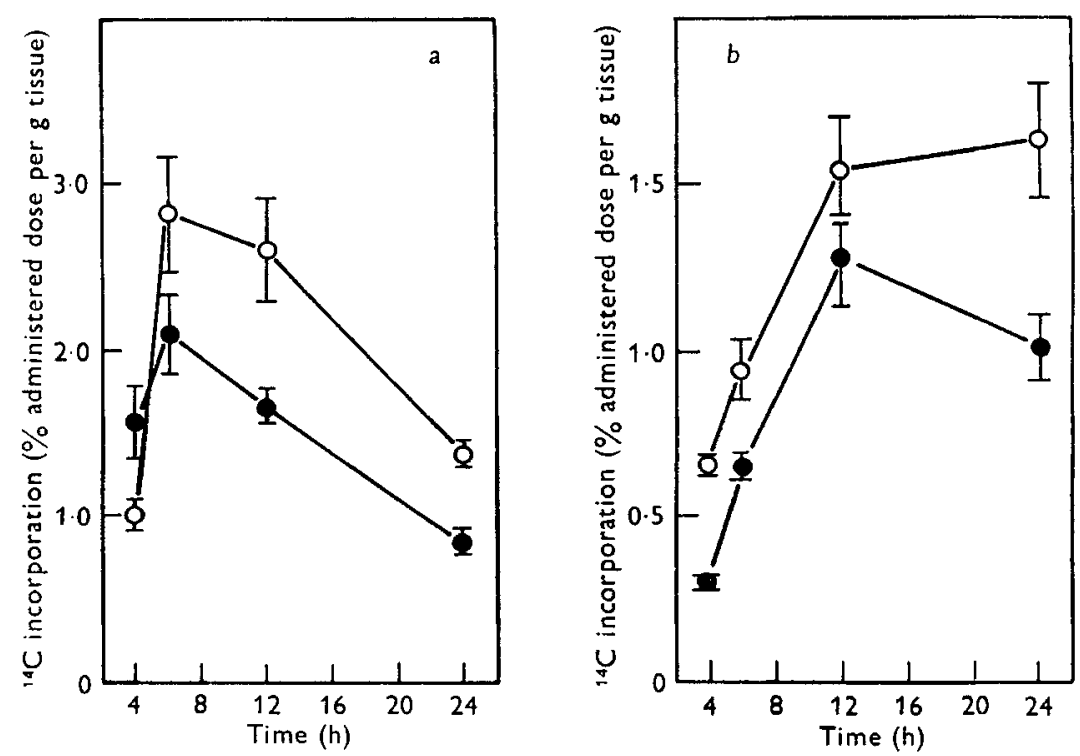

Fig. x. Absorption of cholesterol in (a) intestine and (b) liver of normal ( - - ) and vitamin A-deficient $(\mathrm{O}-\mathrm{O})$ rats. Each value represents the mean of eight individual observations with its standard error.

The results of Expt 3 are presented in Fig. I which shows the percentage of the $\left[4^{-14} \mathrm{C}\right]$ cholesterol incorporated per $\mathrm{g}$ fresh weight of tissue as a function of time in the liver and intestine of both vitamin A-deficient and normal animals and thus gives a measure of the absorption of cholesterol. The radioactivity in the intestine reached the maximum between 4 and $\mathrm{I} 2 \mathrm{~h}$ after dosing in both groups; however, the activity was higher in the vitamin A-deficient animals than in the normal ones. The average 
weight of the small intestine in normal animals was $6.17 \mathrm{~g}$ and $4.89 \mathrm{~g}$ in vitamin Adeficient animals. The radioactivity in both groups then fell rapidly with a concomitant greater uptake by the vitamin A-deficient livers throughout the various time intervals. It was also noteworthy that, while the amount of radioactivity in vitamin Adeficient liver was not significantly different between 12 and $24 \mathrm{~h}$, the normal liver showed a distinct downward trend.
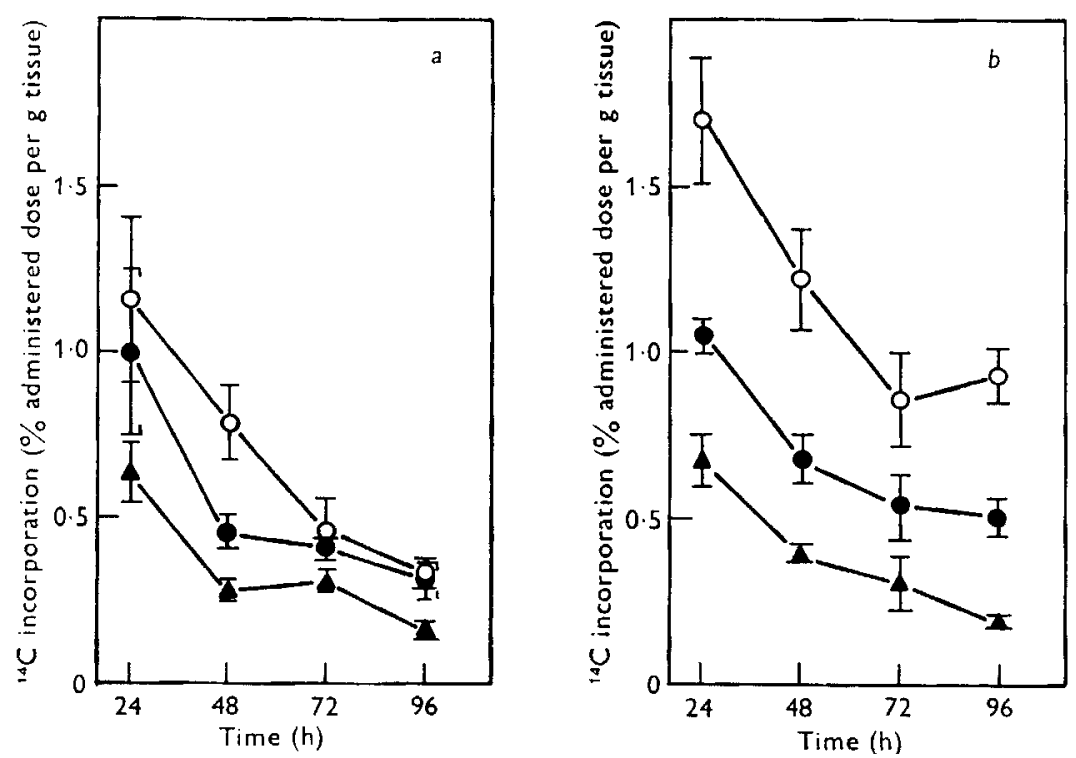

Fig. 2. Absorption and turnover of cholesterol in (a) liver and $(b)$ intestine of normal (- - ) and vitamin $A$-deficient $(\mathrm{O}-\mathrm{O})$ rats and in rats given high levels of vitamin $\mathrm{A}(\boldsymbol{\Lambda}-\mathbf{A})$. Each value represents the mean of six individual observations with its standard error.

Having observed that the absorption of cholesterol was markedly enhanced during vitamin A deficiency the next objective was to investigate whether the turnover rate of cholesterol was affected by vitamin A deficiency or high levels of dietary vitamin A. It was also pertinent to study simultaneously the absorption of cholesterol in rats given high levels of dietary vitamin A. The results of Expt 4 are presented in Fig. 2. The amount of radioactivity per $\mathrm{g}$ of liver at $24 \mathrm{~h}$ was taken as an index of absorption of $\left[4^{-14} \mathrm{C}\right]$ cholesterol and the activity at $48,7^{2}$ and $96 \mathrm{~h}$ as an estimation of the turnover rate. It was apparent that the radioactivity in the liver was increased by $62 \%$ at $24 \mathrm{~h}$ in the vitamin A-deficient group when compared with that from the group given diet 2 containing 400 i.u. vitamin $\mathrm{A} / \mathrm{kg}$. On the other hand, there was a $35 \%$ drop in the amount of radioactivity in the group receiving high levels of vitamin $\mathrm{A}$. The fact that there were no significant differences in the rates at which radioactivity declined in the various groups indicated that vitamin A did not affect the turnover of liver sterols.

\section{DISCUSSION}

Cholesterol feeding is known to increase the hepatic storage of cholesterol in rats. The present studies clearly established that irrespective of the form in which choles- 
terol is fed this effect is accentuated during vitamin A deficiency (Tables $I$ and 2 ) and is more pronounced in males than in females. These findings fully support the earlier observations of Sampson \& Potter (1947). Furthermore, studies on $\left[4-{ }^{14} \mathrm{C}\right]$ cholesterol absorption and turnover have revealed that this effect of vitamin A deficiency is due to an increased rate of cholesterol absorption and not to its decreased turnover rate.

It is interesting here to point out that Horner \& Morton (I960), substantiating the earlier work of Green et al. (1957), state that the effect of cholesterol in depressing the hepatic vitamin A stores of rats is observed only when cholesterol and vitamin $A$ are fed simultaneously. They have also ruled out the possibility of any interference of cholesterol with vitamin A deposition into liver or its utilization. March \& Biely (I963) have obtained similar results from their experiments with chickens. Weitzel, Schön, Gey \& Buddecke (1956) reported that the hypocholesterolaemic effect of vitamin A is not observed if the vitamin is administered to old atherosclerotic hens, indicating that, once hypercholesterolaemia has developed, vitamin A has no beneficiary effect whatsoever. This again suggests that the interference between vitamin $A$ and cholesterol occurs during absorption. Beeler et al. (1962) have found that inclusion of bile salts in the diet of cockerels completely eliminated the hypocholesterolaemic effect of vitamin A. Consequently, they have also proposed that vitamin A or cholesterol mutually interfered with the absorption of the other across the intestine and that vitamin $\mathrm{A}$, in some way, may block the bile salts in facilitating the cholesterol absorption. Strikingly, our results provide a direct evidence for a markedly impaired absorption of cholesterol during feeding of high levels of vitamin A, thus fully supporting the existing concept that vitamin $\mathrm{A}$ and cholesterol do exert a mutual antagonism during absorption. It is, however, interesting to note that neither vitamin A deficiency nor a high level of vitamin $\mathrm{A}$ feeding has any significant effect on the cholesterol turnover rate.

\section{REFEREN CES}

Ahrens, E. H. Jr, Insull, W. Jr, Hirsch, J., Stoffel, W., Peterson, M., Farquhar, J. W., Miller, T. \& Thompson, H. J. (1959). Lancet i, I I 5 .

Anderson, J. T., Keys, A. \& Grande, F. (1957). F. Nutr. 62, 42 I.

Beeler, D. A., Rogler, J. C. \& Quackenbush, F. W. (1962). F. Nutr. 78, 184.

Bring, S. V., Ricard, C. A. \& Zaehringer, M. V. (1965). F. Nutr. 85, 400.

Bronte-Stewart, B., Antonis, A., Eales, L. \& Brock, J. F. (1956). Lancet i, 521.

DeGroot, A. P. \& Reed, S. A. (1959). Nature, Lond. 183, I I9I.

Green, B., Horner, A. A., Lowe, J. S. \& Morton, R. A. (1957). Biochem. F. 67, 235.

Horner, A. A. \& Morton, R. A. (I960). Biochem. Y. 74, 301.

March, B. E. \& Biely, J. (1963). F. Nutr. 79, 474.

Mervyn, L. \& Morton, R. A. (I959). Biochem. F. 72, 106.

Phillips, W. E. J. (196r). Can. F. Biochem. Physiol. 39, 855.

Phillips, W. E. J. (1967). Can. F. Biochem. 45, 749 .

Sampson, M. M. \& Potter, L. M. (1947). Fedn Proc. Fedn Am. Socs exp. Biol. 6, 420.

Weitzel, G., Schön, H., Gey, F. \& Buddecke, E. (1956). Hoppe-Seyler's Z. physiol. Chem. 304, 247.

Wood, J. D. (1 960). Can. F. Biochem. Physiol. 38, 879 .

Wood, J. D. \& Topliff, J. (1961). F. Fish. Res. Bd Can. 18, 377. 